\title{
Branched Phospha[7]triangulanes
}

\author{
J. Chris Slootweg, ${ }^{\dagger}$ Marius Schakel, ${ }^{\dagger}$ Frans J. J. de Kanter, ${ }^{\dagger}$ Andreas W. Ehlers, ${ }^{\dagger}$ \\ Sergei I. Kozhushkov, ${ }^{\ddagger}$ Armin de Meijere, ${ }^{\ddagger}$ Martin Lutz, ${ }^{\S}$ Anthony L. Spek, ${ }^{\S}$ and Koop Lammertsma*,† \\ Department of Chemistry, Faculty of Sciences, Vrije Universiteit, De Boelelaan 1083, \\ 1081 HV Amsterdam, The Netherlands, Institut für Organische und Biomolekulare Chemie der \\ Georg-August-Universität Göttingen, Tammannstrasse 2, D-37077 Göttingen, Germany, and the Bijvoet Center for \\ Biomolecular Research, Crystal and Structural Chemistry, Utrecht University, Padualaan 8, \\ 3584 CH Utrecht, The Netherlands \\ Received December 11, 2003; E-mail: lammert@chem.vu.nl
}

Strain gives cyclopropane derivatives their unique electronic and chemical properties. ${ }^{1}$ Spirofusion of three-membered rings augments the strain by $8.5 \mathrm{kcal} / \mathrm{mol},{ }^{2}$ and yet many stable linear and branched $[n]$ triangulanes are known, ${ }^{3,4}$ but instead only few hetero[ $\left.n\right]$ triangulanes are known, irrespective of whether it concerns spirocyclopropanated aziridines, oxiranes, thiiranes, siliranes, or phosphiranes. $^{3}$ The higher reactivity of the heterocyclic ring is believed to be the underlying cause. In contrast, we now report on the exceptional stability of a branched phospha[7]triangulane.

Reaction of carbene-like terminal phosphinidene complex [ $\mathrm{Ph}-$ $\left.\mathrm{P}=\mathrm{W}(\mathrm{CO})_{5}\right],{ }^{5}$ generated in situ by cheletropic elimination from $\mathbf{1}$ at $100{ }^{\circ} \mathrm{C}$ in toluene, with second-generation bicyclopropylidene $2^{4}$ afforded $\mathrm{W}(\mathrm{CO})_{5}$-complexed phospha[7]triangulane 3 (mp 178$179{ }^{\circ} \mathrm{C}, 88 \%$ ) as the sole product (Scheme 1). Its ${ }^{31} \mathrm{P}$ NMR resonance at $\delta-119.6$ is deshielded by 9.8 from the first-generation triangulane ${ }^{6}$ and by $70.5 \mathrm{ppm}$ from parent $4 .^{7}$ This illustrates little influence of the second spirocyclopropane sphere, but the larger phospha[15]triangulane could not be synthesized from thirdgeneration bicyclopropylidene $5^{4}$ because of its too congested double bond. ${ }^{4 \mathrm{~b}}$
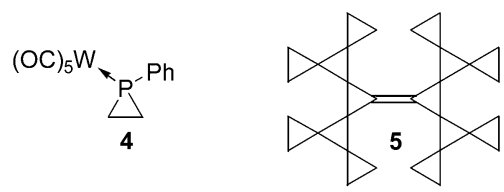

The stabilizing $\mathrm{W}(\mathrm{CO})_{5}$ group was subsequently removed from 3. While oxidation with iodine at $-30{ }^{\circ} \mathrm{C}^{8}$ afforded $\left[\mathrm{W}(\mathrm{CO})_{4} \mathrm{I}\right]^{+} \mathrm{I}^{-}$complexed phospha[7]triangulane $\left[\delta\left({ }^{31} \mathrm{P}\right)-130.1\right]$, quenching with $\mathrm{N}$-methylimidazole ${ }^{8}$ only led to degradation. Instead direct ligand exchange in refluxing xylene $\left(150{ }^{\circ} \mathrm{C} \text { !) with }\left(\mathrm{Ph}_{2} \mathrm{PCH}_{2}\right)_{2} \text { (dppe }\right)^{9}$ was more successful, giving free phospha[7]triangulane 6 ( $\mathrm{mp} \mathrm{168-}$ $169{ }^{\circ} \mathrm{C}, 82 \%$ ) as the sole product (Scheme 2$) .{ }^{10}$ Its $\delta\left({ }^{31} \mathrm{P}\right)$ at -164.0 shows the expected shielding on demetalation, and the increased ${ }^{1} J(\mathrm{P}, \mathrm{C})$ coupling from $6.2(3)$ to $37.3 \mathrm{~Hz}$ resembles that for the parent 1-phenylphosphirane. ${ }^{7,11}$ The molecules of $\mathbf{6}$ are located on an exact mirror plane in the crystal (Figure 1$)^{12}$ and show slightly elongated $\mathrm{P}-\mathrm{C}$ and $\mathrm{P}-\mathrm{Ph}$ bonds (by respectively 0.02 and 0.01 $\AA$ ) due to the absence of the stabilizing $\mathrm{W}(\mathrm{CO})_{5}$ group.

The exceptional thermal stability of $\mathbf{3}$ and $\mathbf{6}$ is remarkable as most phosphiranes eliminate or transfer $\left[\mathrm{Ph}-\mathrm{P}=\mathrm{W}(\mathrm{CO})_{5}\right]$ at much lower temperatures $\left(\leq 100-115^{\circ} \mathrm{C}\right) .{ }^{10}$ That the six spirofused rings indeed stabilize the CCP ring is evident from the mere $6.5 \mathrm{kcal} /$ mol difference in strain energies (SE), determined with homodesmotic reactions at G3(MP2), ${ }^{13}$ between parent phospha[7]triangulane

\footnotetext{
$\dagger$ Vrije Universiteit.

₹ Georg-August-Universität.

$\S$ Utrecht University.
}

Scheme 1. Synthesis of Phospha[7]triangulane Complex 3

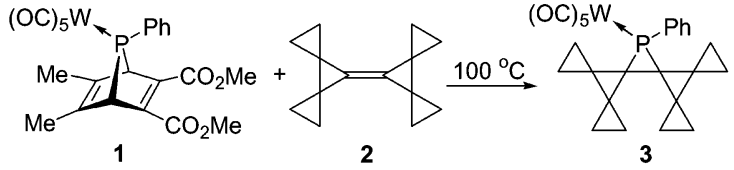

Scheme 2. Decomplexation of 3

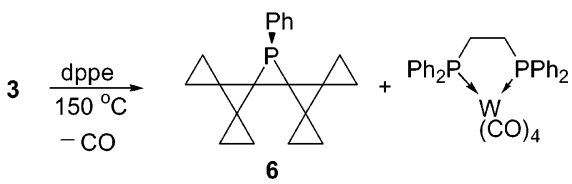

6' ( $\mathrm{H}$ for $\mathrm{Ph} ; 224.2 \mathrm{kcal} / \mathrm{mol})$ and alkene 2 (217.7 kcal/mol); phosphirane $\mathrm{C}_{2} \mathrm{PH}_{5}$ has an $\mathrm{SE}$ of $20.8 \mathrm{kcal} / \mathrm{mol}$. A contributing factor is the release of olefin strain (OS) in 2 that amounts to $23.1 \mathrm{kcal} /$ mol (see Supporting Information). The higher stability of $\mathbf{6}$ is also related to a higher olefinic $\pi$-donor and $\pi^{*}$-acceptor ability in $\mathbf{2}^{4}$ caused by spirocyclopropanation, which is reflected in the $9.3 \mathrm{kcal} /$ mol larger exothermicity for reaction of ${ }^{1} \mathrm{PH}\left(\mathrm{A}_{1}\right)$ with 2 (82.9 $\mathrm{kcal} / \mathrm{mol}$ ) than for ${ }^{1} \mathrm{PH}$ with ethylene $(73.5 \mathrm{kcal} / \mathrm{mol}$; G3(MP2)). This behavior is in line with a higher HOMO $(-8.45 \mathrm{vs}-10.08 \mathrm{eV})$ and a lower LUMO (4.12 vs $4.88 \mathrm{eV}$ ) for 2 when compared to ethylene. ${ }^{14}$

The higher reactivity of alkene $\mathbf{2}$ is also reflected in the $\mathrm{CuCl}-$ catalyzed reaction with $\mathbf{1},{ }^{15}$ but with surprises. Not only does the reaction already take place at room temperature, instead of the usual $55-60{ }^{\circ} \mathrm{C},{ }^{15}$ but it also gives only a modest yield of $\mathbf{3}(42 \%)$ besides

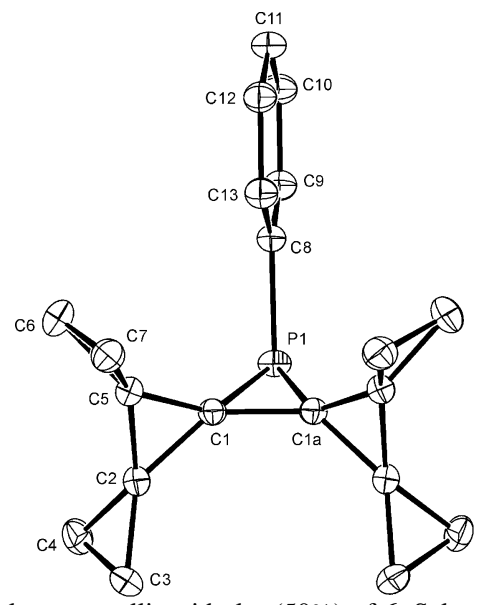

Figure 1. Displacement ellipsoid plot (50\%) of $\mathbf{6}$. Selected bond lengths [A] and angles [deg]: $\mathrm{P} 1-\mathrm{C} 1$ 1.8430(11), C1-C1a 1.470(2), C1-C2 1.4889(14), C1-C5 1.4879(14), C2-C3 1.4862(15), C2-C4 1.4825(15), C2-C5 1.4712(15), C3-C4 1.5305(17), C5-C6 1.4841(15), C5-C7 1.4869(16), C6-C7 1.5262(18); C1-P1-C1a 47.02(6), P1-C1-C1a 66.49(3). A: $x, 0.5-y, z$.

10.1021/ja031648p CCC: $\$ 27.50$ @ 2004 American Chemical Society 


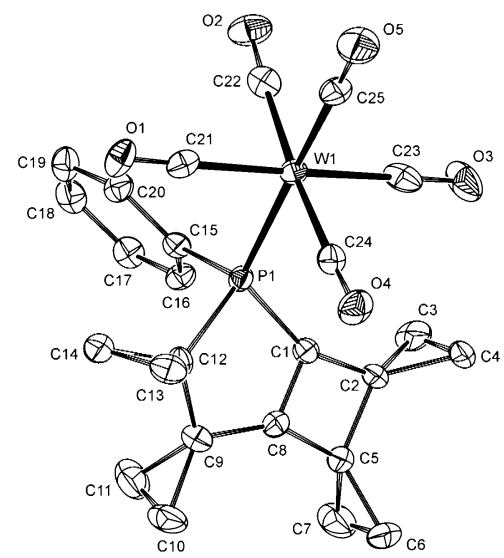

Figure 2. Displacement ellipsoid plot (50\%) of 7 (molecule one of two). Selected bond lengths $[\AA ̊]$ and angles [deg]: P1-C1 1.805(6), P1-C12 1.877(5), C1-C8 1.339(7), C2-C5 1.524(7), C9-C12 1.539(7); C1-P1C12 89.2(3)

Scheme 3. Formation of $\mathbf{3}$ and $\mathbf{7}$ under $\mathrm{CuCl}$ Catalysis

$$
\begin{aligned}
& 1+2 \\
& \text { r.t. } \mid \mathrm{CuCl}
\end{aligned}
$$

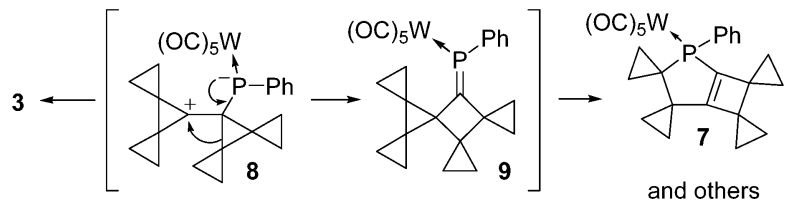

other products, including 7 (6\%) (Scheme 3). ${ }^{16}$ The structure of 7 , the first 2-phosphabicyclo[3.2.0]hept-1(5)-ene derivative, ${ }^{17}$ spirocyclopropanated at each carbon, was established by single-crystal X-ray crystallography (Figure 2)..$^{12}$

The formation of $\mathbf{7}$ is attributed to the influence of $\mathrm{CuCl}$ on the cycloaddition process as $\mathbf{3}$ converts with added $\mathrm{CuCl}$ only slowly in refluxing toluene to 7 and other products. This $\mathrm{CuCl}$-catalyzed cycloaddition behavior concurs with a recent analysis suggesting that a $\mathrm{CuCl}$-alkene complex facilitates the fragmentation of $\mathbf{1}$ to give a reactive $\left[\mathrm{PhP}(\mathrm{Cl}) \mathrm{W}(\mathrm{CO})_{5}\right]-\mathrm{Cu}$-alkene intermediate that subsequently undergoes an $\mathrm{S}_{\mathrm{N}}$ 2-type addition with alkenes. ${ }^{18}$ This bulky $\mathrm{Cu}$-containing reagent likely hampers the concerted [1+2]cycloaddition, thereby enabling the formation of zwitterion $\mathbf{8}$, which can ring-close to $\mathbf{3}$ but also rearrange to $\mathbf{9}$ in analogy to the cyclopropanation reaction of 2 with $\mathrm{N}_{2} \mathrm{CHCO}_{2} \mathrm{Et}$ in which both products were obtained. ${ }^{4 \mathrm{~b}}$ However, contrasting its stable hydrocarbon analogue, the more reactive $\mathrm{P}=\mathrm{C}$ bond of $\mathbf{9}$ enables a subsequent [1,3]-sigmatropic shift ${ }^{19}$ to give 7 . This conversion is $19.9 \mathrm{kcal} / \mathrm{mol}$ exothermic at B3LYP/6-31G* for the parent system ( $\mathrm{H}$ for $\mathrm{Ph}$, no $\left.\mathrm{W}(\mathrm{CO})_{5}\right)^{20}$

In conclusion, a highly strained, thermally stable (up to $150{ }^{\circ} \mathrm{C}$ ) branched phospha[7]triangulane was synthesized from secondgeneration bicyclopropylidene $\mathbf{2}$ and phosphinidene $[\mathrm{Ph}-\mathrm{P}=$ $\mathrm{W}(\mathrm{CO})_{5}$ ], followed by demetalation in refluxing xylene. Bulkier transient $\mathrm{CuCl}$-alkene-complexed phosphinidene gave also a 2-phosphabicyclo[3.2.0]hept-1(5)-ene. Spirocyclopropane-annelation is stabilizing both of these novel compounds.

Acknowledgment. This work was supported by The Netherlands Foundation for Chemical Sciences (CW) with financial aid from The Netherlands Organization for Scientific Research (NWO) and the Fonds der Chemischen Industrie. We are grateful to the companies BASF AG, Bayer AG, Chemetall GmbH, and Degussa AG for generous gifts of chemicals.

Supporting Information Available: Crystallographic data (CIF) of $\mathbf{6}$ and 7, experimental details and spectroscopic and computational data for $\mathbf{3}, \mathbf{6}$, and $\mathbf{7}$ (PDF). This material is available free of charge via the Internet at http://pubs.acs.org.

\section{References}

(1) (a) Cyclopropanes and Related Rings. de Meijere, A., Ed.; Chem. Rev. 2003, 103, 931-1625. (b) Carbocyclic Three-Membered Ring Compounds. Methods of Organic Chemistry (Houben-Weyl); de Meijere, A., Ed.; Thieme: Stuttgart; 1997; Vol. E17a-c. (c) The Chemistry of the Cyclopropyl Group; Rappoport, Z., Ed.; Wiley: Chichester, 1995; Vol. 2.

(2) Beckhaus, H.-D.; Rüchardt, C.; Kozhushkov, S. I.; Belov, V. N.; Verevkin, S. P.; de Meijere, A. J. Am. Chem. Soc. 1995, 117, 11854-11860.

(3) de Meijere, A.; Kozhushkov, S. I. Chem. Rev. 2000, 100, 93-142.

(4) (a) von Seebach, M.; Kozhushkov, S. I.; Boese, R.; Benet-Buchholz, J.; Yufit, D. S.; Howard, J. A. K.; de Meijere, A. Angew. Chem. 2000, 112 2617-2620; Angew. Chem., Int. Ed. 2000, 39, 2495-2498. (b) de Meijere, A.; von Seebach, M.; Zöllner, S.; Kozhushkov, S. I.; Belov, V. N.; Boese, R.; Haumann, T.; Benet-Buchholz, J.; Yufit, D. S.; Howard, J. A. K. Chem.-Eur. J. 2001, 7, 4021-4034.

(5) (a) Lammertsma, K.; Vlaar, M. J. M. Eur. J. Org. Chem. 2002, 11271138. (b) Mathey, F.; Tran Huy, N. H.; Marinetti, A. Helv. Chim. Acta 2001, 84, 2938-2957.

(6) Lammertsma, K.; Wang, B.; Hung, J.-T.; Ehlers, A. W.; Gray, G. M. J. Am. Chem. Soc. 1999, 121, 11650-11655.

(7) (a) Huy, N. H. T.; Mathey, F. Phosphorus, Sulfur Silicon Relat. Elem. 1990, 47, 477-481. (b) Hung, J.-T.; Yang, S.-W.; Gray, G. M.; Lammertsma, K. J. Org. Chem. 1993, 58, 6786-6790.

(8) Marinetti, A.; Mathey, F.; Fischer, J.; Mitschler, A. J. Chem. Soc., Chem. Coтmun. 1984, 45-46.

(9) Deschamps, B.; Mathey, F. Synthesis 1995, 8, 941-943.

(10) Marinetti, A.; Charrier, C.; Mathey, F.; Fischer, J. Organometallics 1985 4, 2134-2138.

(11) Li, X.; Robinson, K. D.; Gaspar, P. P. J. Org. Chem. 1996, 61, 7702-7710.

(12) 6: $\mathrm{C}_{20} \mathrm{H}_{21} \mathrm{P}, \mathrm{FW}=292.34$, colorless needle, $0.46 \times 0.36 \times 0.09 \mathrm{~mm}^{3}$ temperature $=150(2) \mathrm{K}$, monoclinic, $P 2_{1} / m$ (No. 11), $a=7.8462(1), b$ $=12.9734(2), c=8.7058(1) \AA, \beta=115.6968(6)^{\circ}, V=798.537(18) \AA^{3}$, $Z=2, D_{\mathrm{x}}=1.216 \mathrm{~g} / \mathrm{cm}^{3}$. No absorption correction $\left(\mu=0.164 \mathrm{~mm}^{-1}\right)$. 15383 measured reflections, 1913 reflections were unique $\left[(\sin \theta / \lambda)_{\max }\right.$ $\left.=0.65 \AA^{-1}\right] .138$ refined parameters. $R$-values $[I>2 \sigma(I)]: \mathrm{R} 1=0.0307$, $\mathrm{wR} 2=0.0784$. $R$-values [all refl.]: $\mathrm{R} 1=0.0354, \mathrm{wR} 2=0.0812$. GOF $=1.047 .7: \mathrm{C}_{25} \mathrm{H}_{21} \mathrm{O}_{5} \mathrm{PW}, \mathrm{FW}=616.24$, colorless plate, $0.09 \times 0.09 \times$ $0.03 \mathrm{~mm}^{3}$, temperature $=150(2) \mathrm{K}$, orthorhombic, $P c a 2_{1}$ (no. 29), $a=$ 18.9647(1), $b=11.3278(1), c=21.7733(2) \AA, V=4677.52(6) \AA^{3}, Z=$ $8, D_{\mathrm{x}}=1.750 \mathrm{~g} / \mathrm{cm}^{3}$. Analytical absorption correction $\left(\mu=5.041 \mathrm{~mm}^{-1}\right.$, $0.58-0.89$ transmission). 80568 measured reflections, 10736 reflections were unique $\left[(\sin \theta / \lambda)_{\max }=0.65 \AA^{-1}\right] .577$ refined parameters. Flack parameter $x=-0.022(5) . R$-values $[I>2 \sigma(I)]: \mathrm{R} 1=0.0285$, wR2 $=$ 0.0378. $R$-values [all refl.]: $\mathrm{R} 1=0.0450, \mathrm{wR} 2=0.0405 . \mathrm{GOF}=0.975$. (See Supporting Information for crystal structure determinations.)

(13) (a) Curtiss, L. A.; Redfern, P. C.; Raghavachari, K.; Rassolov, V.; Pople, J. A. J. Chem. Phys. 1999, 110, 4703-4709. (b) Frisch, M. J.; Trucks, G. W.; Schlegel, H. B.; Scuseria, G. E.; Robb, M. A.; Cheeseman, J. R.; Zakrzewski, V. G.; Montgomery, J. A., Jr.; Stratmann, R. E.; Burant, J. C.; Dapprich, S.; Millam, J. M.; Daniels, A. D.; Kudin, K. N.; Strain, M. C.; Farkas, O.; Tomasi, J.; Barone, V.; Cossi, M.; Cammi, R.; Mennucci, B.; Pomelli, C.; Adamo, C.; Clifford, S.; Ochterski, J.; Petersson, G. A.; Ayala, P. Y.; Cui, Q.; Morokuma, K.; Malick, D. K.; Rabuck, A. D.; Raghavachari, K.; Foresman, J. B.; Cioslowski, J.; Ortiz, J. V.; Stefanov, B. B.; Liu, G.; Liashenko, A.; Piskorz, P.; Komaromi, I.; Gomperts, R.; Martin, R. L.; Fox, D. J.; Keith, T.; Al-Laham, M. A.; Peng, C. Y. Nanayakkara, A.; Gonzalez, C.; Challacombe, M.; Gill, P. M. W.; Johnson, B. G.; Chen, W.; Wong, M. W.; Andres, J. L.; Head-Gordon, M.; Replogle, E. S.; Pople, J. A. Gaussian 98, revision A.11.3; Gaussian, Inc.: Pittsburgh, PA, 2002. (c) See Supporting Information.

(14) Orbital energies at MP2/6-31G*.13b The lowest ionization energies $(\pi$ $\mathrm{IE}_{\mathrm{v}}$ ) determined by PE spectroscopy are $8.93 \mathrm{eV}$ for bicyclopropylidene (Gleiter, R.; Haider, R.; Conia, J.-M.; Barnier, J.-P.; de Meijere, A.; Weber, W. J. Chem. Soc, Chem Commun 1979, 130-132. Hofland, A.; de Boer, Th. J. Recl. Trav. Chim. Pays-Bas 1987, 106, 558-562. Gleiter, R. Spanget-Larson, J. In Advances in Strain in Organic Chemistry; Halton, B., Ed.; JAI Press: London, 1992; Vol. 2, p 143ff), $8.70 \mathrm{eV}$ for 1-(cyclopropylidene)spiropentane, and $8.50 \mathrm{eV}$ for 7-(cyclopropylidene)dispiro-[2.0.2.1]heptane) (Gleiter, R.; Kozhushkov, S. I.; de Meijere, A. unpublished results).

(15) Marinetti, A.; Mathey, F. Organometallics 1984, 3, 456-461.

(16) A byproduct in the crude reaction mixture [ca. $20 \% ; \delta\left({ }^{31} \mathrm{P}\right)=119.5,{ }^{1} J_{\mathrm{P}-\mathrm{W}}$ $=254.4 \mathrm{~Hz}]$ did not survive workup.

(17) To our knowledge, only a 3-phosphabicyclo[3.2.0]heptene has been reported earlier: Quin, L. D.; Middlemas, E. D. J. Am. Chem. Soc. 1977, 99, 8370-8371.

(18) Lammertsma, K.; Ehlers, A. W.; McKee, M. L. J. Am. Chem. Soc. 2003 $125,14750-14759$.

(19) Bulo, R. E.; Ehlers, A. W.; Grimme, S.; Lammertsma, K. J. Am. Chem Soc. 2002, 124, 13903-13910. This rearrangement of 9 is a heteroanalogue of the vinylcyclopropane-cyclopentene rearrangement: Baldwin, J. E. In The Chemistry of the Cyclopropyl Group; Rappoport, Z., Ed.; Wiley: Chichester, 1995; Vol. 2, pp 469-494. Baldwin, J. E. J. Comput. Chem. 1998, 19, 222-231. Baldwin, J. E. Chem. Rev. 2003, 103, 1197-1212.

(20) The geometries of $\mathbf{9}^{\prime}$ and $7^{\prime}$ ( $\mathrm{PH}$ instead of $\left.\mathrm{PhPW}(\mathrm{CO})_{5}\right)$ were optimized at the B3LYP/6-31G* level (see Supporting Information). ${ }^{13 \mathrm{~b}}$ JA031648P 